\title{
Ontogenic and nutritional regulation of steroid receptor and IGF-I transcript abundance in the prepubertal heifer mammary gland
}

\author{
M J Meyer, R P Rhoads, A V Capuco ${ }^{1}$, E E Connor ${ }^{1}$, A Hummel ${ }^{1}$, Y R Boisclair and M E Van Amburgh \\ Department of Animal Science, Cornell University, 272 Morrison Hall, Ithaca, New York 14850, USA \\ ${ }^{1}$ Bovine Functional Genomics Lab, USDA-ARS, Beltsville, Maryland 20705, USA \\ (Correspondence should be addressed to M E Van Amburgh; Email: mev1@cornell.edu) \\ M J Meyer is now at Mammary Biology and Tumorigenesis Laboratory, National Cancer Institute, National Institutes of Health, 37 Convent Drive, Building 37 , \\ Room 1108, Bethesda, Maryland 20892, USA \\ R P Rhoads is now at Department of Animal Sciences, University of Arizona, Tucson, Arizona 85721, USA
}

\begin{abstract}
In prepubertal cattle, mammary development is characterized by the growth of an epithelial-rich parenchyma (PAR) into the mammary fat pad (MFP). This proliferation and accumulation of mammary epithelial cells require estrogen. Paradoxically, both epithelial cell proliferation and PAR accumulation rate decline with rising plasma estrogen as puberty approaches. The possibility that variation in abundance of estrogen receptors (ERs) in PAR or MFP accounts for a portion of these effects has not been examined in cattle. Additionally, we recently demonstrated that MFP is highly responsive to exogenous estrogen, suggesting that this tissue may play a role in coordinating estrogen's effects on PAR; however, the developing bovine MFP has yet to be studied in detail. To address these hypotheses, Holstein heifers were assigned to planes of nutrition supporting body growth rates of $950(\mathrm{E})$ or $650(\mathrm{R}) \mathrm{g} /$ day and harvested every $50 \mathrm{~kg}$ from 100 to $350 \mathrm{~kg}$ body weight (BW). Post-harvest, their mammary glands were dissected into PAR and MFP
\end{abstract}

compartments. Transcript abundance of genes encoding members of the ER family (ER $\alpha, E R \beta$, and estrogen-related receptor $\alpha-1($ ERR $\alpha)$ ) and estrogen-responsive genes (IGF-I and progesterone receptor $(P R)$ ) were measured in both mammary compartments by quantitative real-time RT-PCR. Significant expression was detected for all genes in both compartments, with the exception of the ER $\beta$ gene. Transcript abundance of both ER $\alpha$ and IGF-I decreased linearly with increasing BW within both compartments. ERR $\alpha$ and PR expressions decreased with increasing $B W$ in PAR but not in MFP. Nutrition stimulated ER $\alpha$ and ERR $\alpha$ expression in the PAR but had no effect on IGF-I or PR in either PAR or MFP. Overall, ER $\alpha$ and IGF-I transcript abundance are consistent with the drop in mammary epithelial cell proliferation and PAR accretion observed over development, but do not support a negative effect of nutrition on PAR growth.

Journal of Endocrinology (2007) 195, 59-66

\section{Introduction}

Growth of the mammary parenchymal compartment does not occur when prepubertal cattle are ovariectomized (Wallace 1953, Purup et al. 1993). The apparent requirement of ovarian stimulation presumably reflects an obligatory role for the low plasma concentration of estrogen present in prepubertal cattle (Evans et al. 1994). Estrogen's influence is mediated by the estrogen receptor (ER) family, which include $\mathrm{ER} \alpha, \mathrm{ER} \beta$, and three estrogen-related receptors (ERRs). At this time, the functional significance of these receptors for mammary development of prepubertal cattle can only be inferred from rodents. In the mouse, ER $\alpha$ is the most important receptor as shown by the absence of mammary ductal elongation in the ER $\alpha$ knockout mouse but normal development in the ER $\beta$ knockout mouse (Couse \& Korach 1999). In rodents, $E R \alpha$ is expressed in mammary epithelial and stromal cells, and paracrine signaling appears to mediate mammogenic effects of estrogen. Although initial studies indicated that estrogen-mediated developmental signals require ER $\alpha$ expression in stromal cells (Cunha et al. 1997, Mueller et al. 2002), recent studies show that ER $\alpha$ expression in mammary epithelium is most important (Mallepell et al. 2006). However, stromal ER $\alpha$ expression allows estradioldependent synthesis of growth factors, such as insulin-like growth factor-I (IGF-I), which then stimulate epithelial cell proliferation (Imagawa et al. 1986, Shamay et al. 1988). We recently demonstrated a similar effect of estrogen on IGF-I transcript abundance in the bovine mammary fat pad (MFP; Li et al. 2006, Meyer et al. 2006a). The essential role of IGF-I in the developing murine mammary gland is illustrated by the absence of ductal elongation and branching in the IGF-I knockout mouse (Ruan \& Kleinberg 1999). In contrast, far less is known about the role of the three ERRs in mammary 
gland development. One of them, the ERR $\alpha$ shares considerable homology with ER $\alpha$ (Giguere 2002). Although unable to bind estrogen, ERR $\alpha$ can modulate estrogendependent responses (Kraus et al. 2002).

We recently showed that proliferation and accumulation of mammary epithelial cells decrease as heifers progress from birth through puberty (Ellis \& Capuco 2002, Meyer et al. 2006c). In addition, nutrient intake sustaining average daily gains in excess of $850 \mathrm{~g} /$ day has been associated with decreased growth of the mammary epithelial compartment (Sejrsen et al. 1982, 2000, Capuco et al. 1995). The possibility that changes in the expression of members of the ER family $(\mathrm{ER} \alpha, \mathrm{ER} \beta$, and $\mathrm{ERR} \alpha)$ and their response genes (IGF-I and progesterone receptor $(P R)$ ) could explain variation in parenchyma (PAR) growth has not been studied during prepubertal development. This hypothesis is supported by variation in PAR ER $\alpha$ expression from mammogenesis through lactogenesis and involution in cattle (Schams et al. 2003, Connor et al. 2005). This information is also lacking for the MFP, which is known to modulate epithelial growth in an estrogen-dependent manner in mice (Cunha et al. 1997, Mueller et al. 2002) and is hypothesized to do so in the bovine (Meyer et al. 2006a). Significantly, we were the first to demonstrate that $E R \alpha$ is expressed and functionally active in the bovine MFP (Meyer et al. 2006a). The current experiment characterizes developmental and nutritional regulation of $\mathrm{ER} \alpha$ within the bovine MFP in detail not previously described.

To determine whether changes in expression of genes of the ER family and select target genes within the PAR or MFP can explain variation in PAR growth, heifers were fed to gain at a restricted rate of $650 \mathrm{~g} /$ day or at an elevated rate of $950 \mathrm{~g} /$ day between birth and puberty, and PAR and MFP were obtained at $50 \mathrm{~kg}$ body weight (BW) intervals from 100 to $350 \mathrm{~kg} \mathrm{BW}$. We then measured the expression of genes encoding members of the ER family $(\mathrm{ER} \alpha, \mathrm{ER} \beta$, and ERR $\alpha$ ) and estrogen-responsive genes (IGF-I and $P R)$ in both mammary compartments.

\section{Materials and Methods}

\section{Animals and tissue collection}

The Cornell University Animal Care and Use Committee approved all procedures used in this study. Seventy-two Holstein heifers were purchased from commercial dairy farms and assigned at day 10 of life to a $2 \times 6$ factorial design. The first factor consisted of the plane of nutrition, with heifers fed to gain at the restricted rate of $650 \mathrm{~g} /$ day $(\mathrm{R})$ or at the elevated rate of $950 \mathrm{~g} /$ day $(\mathrm{E})$. The second factor was $\mathrm{BW}$ at harvest $(100,150,200,250,300$, or $350 \mathrm{~kg})$. Once heifers reached $225 \mathrm{~kg} \mathrm{BW}$, blood was collected twice weekly via jugular venipuncture and assayed for progesterone (Coat-ACount progesterone RIA, Diagnostic Products Corporation, Los Angeles, CA, USA). Heifers were declared pubertal if plasma progesterone exceeded $1 \mathrm{ng} / \mathrm{ml}$. If pubertal at the assigned harvest $\mathrm{BW}$, heifers were harvested in the luteal phase of their reproductive cycle. Humane slaughter was conducted by stunning with a captive bolt and exsanguination at the Cornell University abattoir.

\section{Mammary gland dissection and immunohistochemistry}

The mammary gland was removed and weighed at harvest. The left half was immediately dissected and tissue from the mid-PAR and MFP were snap frozen in liquid nitrogen for RNA extraction. Additional tissue samples from these same regions were fixed overnight in $10 \%$ neutral buffered formalin at $4{ }^{\circ} \mathrm{C}$ and then stored in $70 \%$ ethanol until paraffin embedding and sectioning.

Tissue sections were processed for immunohistochemical detection of ER and PR using the Histostain SP kit (Zymed Laboratories, San Francisco, CA, USA) as described previously (Capuco et al. 2002). Primary antibody for ER localization was mouse monoclonal antibody C-311 produced against amino acid sequence $405-595$ of the bovine ER $\alpha$ (Santa Cruz Biotechnology Inc., Santa Cruz, CA, USA). Primary antibody for PR localization was mouse monoclonal antibody, Clone PR-AT4.14 (Research Diagnostics Products Inc., Flanders, NJ, USA) that recognizes A and B forms of PR. To quantify the number of labeled cells, photographs of stained sections were captured as digital images. For each animal, ten random areas from a single-stained slide were photographed with a Spot digital camera (Diagnostic Instruments Inc., Sterling Heights, MI, USA) on a Zeiss Axioskop microscope (Carl Zeiss Inc., Thornwood, NY, USA) at $400 \times$ magnification. Labeled epithelial cells and total epithelial cells per micrograph were counted manually. At least 4000 mammary epithelial cells were scored per animal.

\section{RNA isolation and quantitative real-time RT-PCR}

Of the 12 heifers slaughtered at each BW, five $\mathrm{E}$ heifers and five $\mathrm{R}$ heifers were randomly selected (for a total of 60 heifers) for isolation of total RNA and quantitative real-time RT-PCR analysis. Total RNA was isolated by the acid guanidinium thiocyanate-phenol-chloroform method (Chomczynski \& Sacchi 1987) and quantified by absorbance at $260 \mathrm{~nm}$. Fifteen micrograms of total RNA were treated with DNA-free (Ambion, Austin, TX, USA) DNase to remove any DNA contamination. Quality and quantity of the DNase-treated RNA was determined using the Agilent 2100 Bioanalyzer (Agilent Technologies, Palo Alto, CA, USA). DNase-treated RNA (990 ng) was reverse transcribed using the iScript cDNA Synthesis Kit (Bio-Rad Laboratories) in a $20 \mu \mathrm{l}$ reaction mix. The reverse transcription conditions were as follows: $5 \mathrm{~min}$ at $25^{\circ} \mathrm{C}, 30 \mathrm{~min}$ at $42^{\circ} \mathrm{C}$, and $5 \mathrm{~min}$ at $85^{\circ} \mathrm{C}$.

Transcript abundance was determined by SYBR green quantitative real-time RT-PCR (iQ SYBR Green Supermix, Bio-Rad Laboratories) using the iCycler iQ (Bio-Rad Laboratories). A total of $2 \cdot 0 \mu \mathrm{l}$ RT reaction mix was used in each PCR. Primers and PCR conditions for the ER $\alpha, E R \beta$, 
ERR $\alpha 1$, and PR RT-PCR assays were described recently (Connor et al. 2005). Forward and reverse primers for evaluation of IGF-I gene expression were 5'-CATCCTCCTCGCATCTCTTC- $3^{\prime}$ and $5^{\prime}$-GCACACGAACTGGAGAGC- $3^{\prime}$ respectively $\left(T_{\mathrm{m}}=57 \cdot 0{ }^{\circ} \mathrm{C} ; 118 \mathrm{bp}\right.$ product $)$. Amplicons were verified for each assay by sizing on an Agilent 2100 Bioanalyzer and sequencing. Copy numbers for each transcript were calculated from standard curves based on purified amplicons. Melting curve analysis confirmed the presence of a single product for each real-time RT-PCR assay.

\section{Statistical analysis}

Data were analyzed by a general linear model accounting for plane of nutrition, BW at slaughter and their interaction, with the level of statistical significance set at $P<0 \cdot 05$. When $\mathrm{BW}$ at slaughter was significant, variation was partitioned into linear, quadratic, and cubic contrasts. This analysis excluded outliers, defined as data with residuals falling two s.D.s beyond the residual mean.

\section{Results}

\section{Mammary development}

$\mathrm{R}$ and $\mathrm{E}$ heifers grew at the average rate of 0.66 and $0.93 \mathrm{~kg} /$ day respectively. Their mammary development has previously been described (Meyer et al. 2006b,c). Briefly, at a common BW, the mass of PAR DNA was less in E than R heifers. This effect of nutrition was not explained by a slower PAR DNA accretion rate or mammary epithelial cell proliferation in $\mathrm{E}$ heifers, but rather by a shorter lifespan between birth and slaughter. Finally, irrespective of level of nutrient intake, mammary epithelial cell proliferation was greatest at $100 \mathrm{~kg} \mathrm{BW}$, after which it decreased with increasing BW. Additionally, PAR DNA accretion dropped markedly as heifers approached puberty.

\section{Expression of ER family members}

Within the PAR, abundance of the ER $\alpha$ gene transcript was not affected by the plane of nutrition (data not shown). However, there was a negative linear relationship between PAR ER $\alpha$ mRNA abundance and BW, with ER $\alpha$ transcript abundance decreasing by a factor of five between 100 and $350 \mathrm{~kg} \mathrm{BW}(P<0 \cdot 01$; Fig. 1). As shown previously, ER $\alpha$ protein was localized to epithelial cells and to a rare fraction of fibroblasts (Capuco et al. 2002, Schams et al. 2003), which appear primarily in the interlobular connective tissue (Capuco, unpublished data).

ER $\propto$ mRNA abundance in MFP was comparable with that in PAR (Figs 1 and $2 \mathrm{~A}$ and $\mathrm{B}$ ) and ER $\alpha$ transcript abundance in R heifers' MFP was $\sim 60 \%$ of that in E heifers $(P=0 \cdot 03$; Fig. 2A). A cubic relationship between $E R \alpha$ transcript abundance and $\mathrm{BW}$ at slaughter was observed, wherein expression reached a peak at 100 and $250 \mathrm{~kg}$ and a nadir at 150

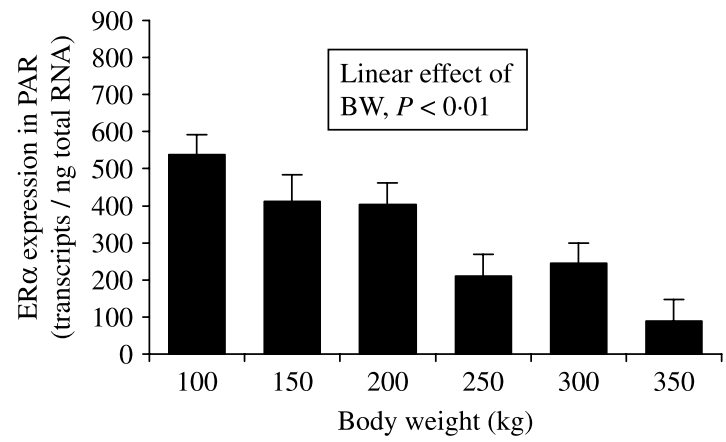

Figure 1 Effect of body weight (BW) on expression of the gene encoding estrogen receptor $\alpha(E R \alpha)$ within the mammary parenchyma (PAR). Dairy heifers were offered a restricted or an elevated plane of nutrition starting at day 10 of age and harvested at fixed BW $(100-350 \mathrm{~kg})$. Total RNA was isolated from PAR and assayed by quantitative RT-PCR for ER $\alpha$ transcript copy number. In all cases, transcript copy number was normalized to the amount of total RNA used in the reverse transcription reaction. The plane of nutrition did not influence transcript abundance so only main effect of BW is presented $(n=10,7,9,9,10$, and 9 for 100, 150, 200, 250, 300, and $350 \mathrm{~kg}$ respectively). Bars represent means \pm s.E.M. Variation in BW was partitioned into linear, quadratic, and cubic contrasts, and any significant contrast was reported.

and $350 \mathrm{~kg}(P=0.03$; Fig. 2B). Given the dearth of information on the bovine MFP, relative to PAR, expression and localization of ER protein across prepubertal development were also assessed. Consistent with first published reports of ER $\alpha$ localization in the bovine MFP (Meyer $e t$ al. 2006a), we observed expression of the receptor in both fibroblasts (Fig. 3A) and adipocytes (Fig. 3A) in the current study. ER $\alpha$ immunoreactivity was detected in $\sim 30 \%$ of MFP fibroblasts and adipocytes (Fig. 3C and D). Neither increasing BW nor level of nutrient intake affected the fraction of either cell type expressing the ER $\alpha$ protein.

ERR $\alpha$ mRNA was more abundant in both PAR and MFP of $\mathrm{E}$ than $\mathrm{R}$ heifers $(P \leq 0 \cdot 05$, Fig. $4 \mathrm{~A}$ and $\mathrm{B})$. A negative linear relationship was observed between ERR $1 \alpha$ mRNA abundance within PAR and BW at slaughter (Fig. 4C; $P=0.04$ ); no such effect was detected in MFP (data not shown). Finally, copy number of ER $\beta$ transcripts was below the lowest standard (equivalent to one transcript per ng total RNA) in both mammary compartments, irrespective of BW or nutrition (data not shown).

\section{Expression of E-dependent genes}

Plane of nutrition did not alter abundance of IGF-I transcripts in PAR or MFP (data not shown). In both mammary compartments, IGF-I mRNA abundance decreased linearly with increasing $\mathrm{BW}(P<0 \cdot 05$; Fig. $5 \mathrm{~A}$ and $\mathrm{B})$. In the MFP, the effect of $\mathrm{BW}$ was dominated by a drop in transcript abundance between 100 and $150 \mathrm{~kg} \mathrm{BW}$ with little additional variation at higher BW.

We also assessed mammary expression of the $P R$ gene, which is stimulated by estrogen in the PAR (Meyer et al. 

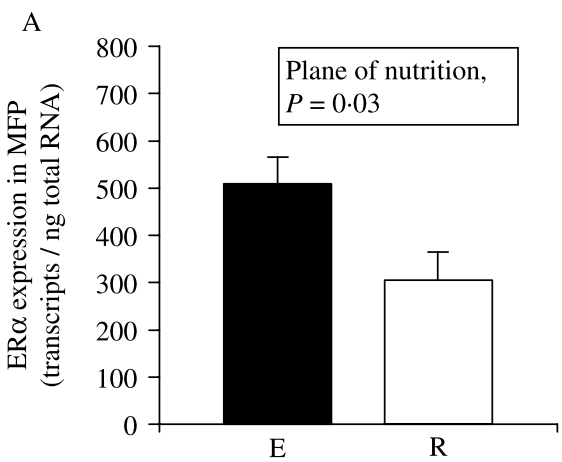

Plane of nutrition

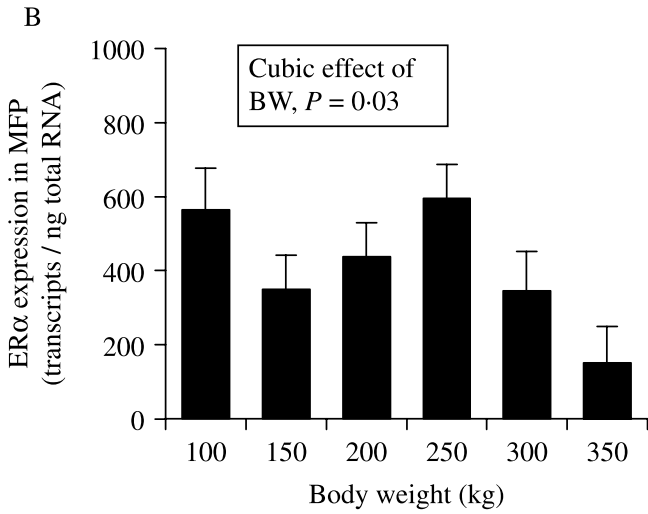

Figure 2 Effect of nutrition and body weight (BW) on expression of the gene encoding estrogen receptor $\alpha$ $(E R \alpha)$ within the mammary fat pad (MFP). Dairy heifers were offered a restricted (R) or an elevated (E) plane of nutrition starting at day 10 of age and harvested at fixed BW (100-350 kg). (A and B) Total RNA was isolated from the MPF and assayed by quantitative RT-PCR for ER $\alpha$ transcript copy number. In all cases, transcript copy number was normalized to the amount of total RNA used in the reverse transcription reaction. (A) Main effect of plane of nutrition (E (solid bar), $n=28$ versus $\mathrm{R}$ (open bar), $n=26$ ). Bars represent means \pm S.E.M. (B) Main effect of BW on transcript abundance $(n=7,10,10,10,8$, and 9 for 100, 150, 200, 250,300, and $350 \mathrm{~kg}$ respectively). Bars represent means \pm s.E.M. Variation in BW was partitioned into linear, quadratic, and cubic contrasts, and any significant contrast was reported.

2006a). PR gene expression was approximately tenfold higher in the PAR than in the MFP (data not shown). Plane of nutrition had no influence on PR mRNA abundance in PAR or MFP (data not shown). PR mRNA abundance decreased linearly with BW in PAR $(P<0 \cdot 01$; Fig. $5 \mathrm{C})$, but remained invariant in MFP (data not shown). Consistent with the low abundance of PR mRNA in MFP, few if any cells in this mammary compartment stained positive for PR by immunohistochemistry (data not shown).

\section{Discussion}

In both mice and cattle, mammary development between birth and puberty is characterized by the accumulation of epithelial ductal structures (Silberstein 2001, Capuco et al. 2002). The ducts elongate until they reach the edge of the fat pad in the mature nulliparous mouse, whereas they grow as a dense mass within the fat pad in cattle and do not appear to reach the margins of the fat pad until gestation in cattle. Despite these morphological differences, epithelial growth is dependent on estrogen in both species (Wallace 1953, Purup et al. 1993). Proliferating epithelial cells, however, rarely express ER $\alpha$, suggesting that estrogen induces the synthesis of locally acting growth factors such as IGF-I in ER-positive, non-proliferating cells. Experiments involving genetically altered mice show that these cells reside in both PAR and MFP compartments (Cunha et al. 1997). Although most studies in cattle have examined only PAR (Schams et al. 2003, Connor et al. 2005), recent data from our group support a role for the MFP. Specifically, estrogen stimulated IGF-I gene expression to a greater extent in MFP than in PAR (Meyer et al. 2006a), and the greatest degree of mammary epithelial cell proliferation occurs in the region of PAR adjacent to
MFP (Capuco et al. 2002). For these reasons, we studied the expression of ER family members and E-dependent genes in both mammary compartments. Further, ER protein expression was evaluated in the MFP due to the lack of data on this mammary compartment in the bovine.

The regulation of ER $\alpha$ differed between PAR and MFP. We observed that $\mathrm{ER} \alpha$ transcript in PAR gradually declines from a peak at $100 \mathrm{~kg} \mathrm{BW}$ to a nadir at $350 \mathrm{~kg} \mathrm{BW}$, when puberty was reached. This indicates that $\operatorname{ER} \alpha$ transcript abundance decreases prior to puberty and is consistent with data from gestating heifers (Connor et al. 2005). A similar ontogenic effect was not obvious in MFP between 100 and $250 \mathrm{~kg} \mathrm{BW}$, although a nadir was clearly seen at $350 \mathrm{~kg} \mathrm{BW}$. This difference may relate to the ability of rising $\mathrm{E}$ to repress ER $\alpha$ expression in PAR but not in MFP (Meyer et al. 2006a). A second difference between PAR and MFP may be the relation between $\mathrm{ER} \alpha$ expression and the fraction of ER-positive cells. We showed that these two variables are well correlated in the PAR (Meyer et al. 2006c), but this was not seen in the MFP in the present study, with the fraction of adipocytes or fibroblasts expressing ER $\alpha$ remaining constant even when the transcript copy number reached its nadir at $350 \mathrm{~kg} \mathrm{BW}$. This implies decreased immunoreactive ER $\alpha$ per cell and/or significant post-transcriptional regulation of this receptor in the MFP.

Next, we investigated the possibility that other members of the ER family are involved in bovine mammary development. In the mouse, ER $\beta$ has been proposed to play a role in coordinating the responsiveness of the mammary gland to estrogen and is actually the primary isoform expressed in MFP (Cheng et al. 2004). In contrast, we detected extremely low levels of ER $\beta$ mRNA in the bovine MFP, and in agreement with previous work of ours 

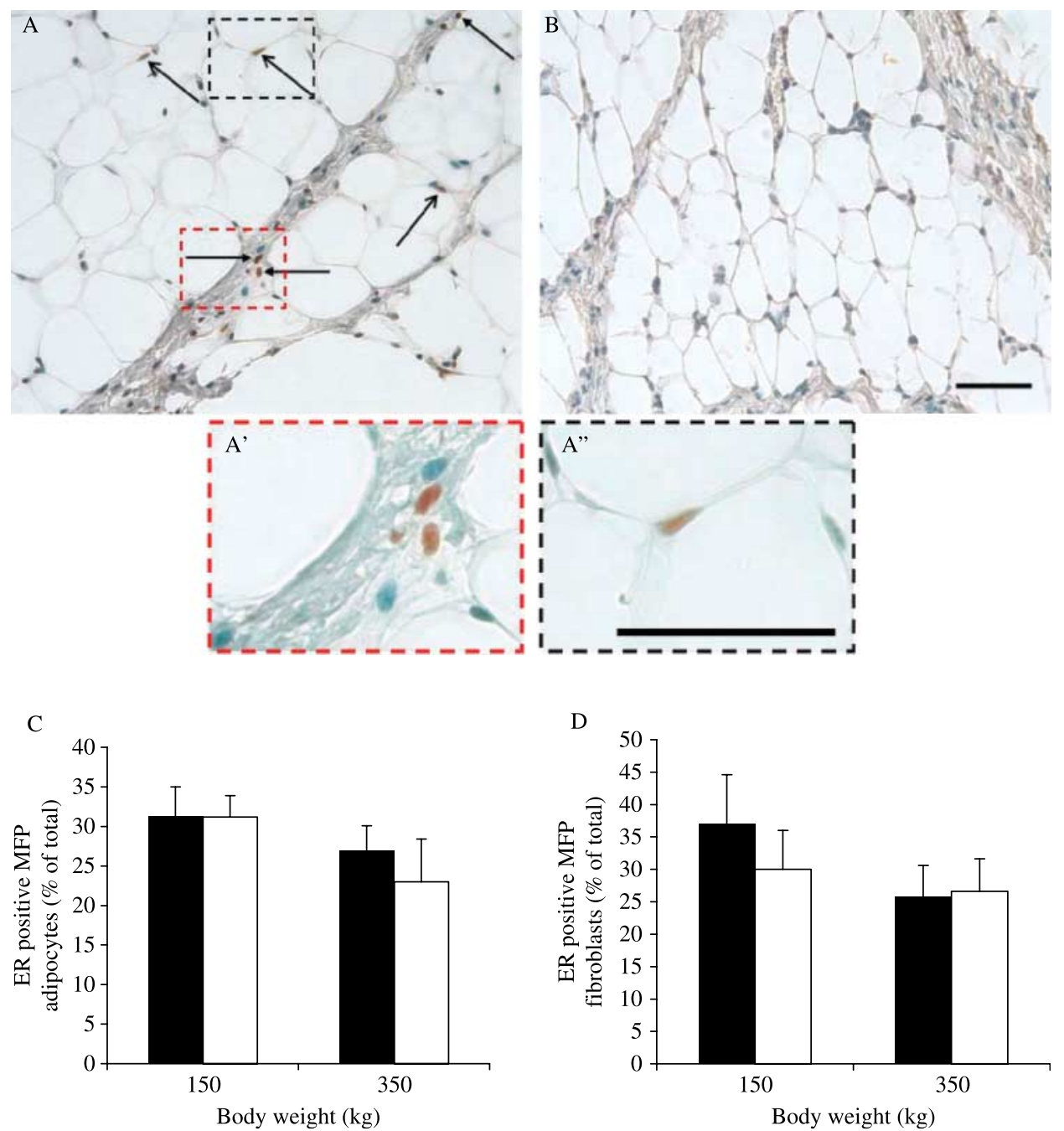

Figure 3 Effect of nutrition and body weight (BW) on expression of the gene encoding estrogen receptor $\alpha$ $(E R \alpha)$ within the mammary fat pad (MFP). Dairy heifers were offered a restricted (R) or an elevated (E) plane of nutrition starting at day 10 of age and harvested at fixed BW (100-350 kg). (A and B) ER $\alpha$ localization within the prepubertal bovine MFP. Twelve prepubertal dairy heifers were raised on an elevated or restricted plane of nutrition from birth and harvested at 150 and $350 \mathrm{~kg}$ BW. Tissue collected from the MFP was analyzed for immunoreactive $\mathrm{ER} \alpha$. A representative $150 \mathrm{~kg}$ BW heifer is shown. (A) Closed arrow indicates examples of ER-positive fibroblasts and open arrows indicate ER-positive adipocytes. Higher magnification of ER-positive fibroblast (insert $A^{\prime}$ : dashed red box) and ER-positive adipocytes (insert $A^{\prime \prime}$ : dashed black box) is provided. Magnification bar $=50 \mu \mathrm{m}$. (B) Staining with control serum. Magnification bar $=50 \mu \mathrm{m}$. (C and D) Effect of BW on the percent of adipocytes (C) and fibroblasts (D) within the MFP that stain positive for ER as assessed by immunohistochemistry. Elevated plane of nutrition is represented by the solid bars and restricted plane of nutrition by the open bars. No effect of nutrition or BW was detected. In all cases, bars represent means \pm S.E.M. For (C), $150 \mathrm{~kg}, n=12$ and $350 \mathrm{~kg}, n=11$. For (D), $150 \mathrm{~kg}, n=12$ and $350 \mathrm{~kg}, n=11$.

and others (Schams et al. 2003, Connor et al. 2005), in PAR. Overall, these data suggest that this gene likely plays no significant role in coordinating mammary development in cattle. We also measured expression of the orphan receptor ERR $\alpha$ which shares considerable homology with ER $\alpha$ (Giguere 2002) and is known to influence transcription of estrogen-responsive genes (Zhang \& Teng 2001). In the current study, ERR $\alpha 1$ transcript abundance within PAR gradually decreased with increasing BW but no such regulation was observed in MFP.

IGF-I and PR transcript copy numbers are increased by estrogen in PAR (Woodward et al. 1993, Meyer et al. 2006a) and MFP (Meyer et al. 2006a) of prepubertal heifers and consequently could provide an index of ER-dependent effects. IGF-I gene expression in PAR declined with increasing $\mathrm{BW}$, mimicking the age-dependent decline in ER $\alpha$ and epithelial cell 


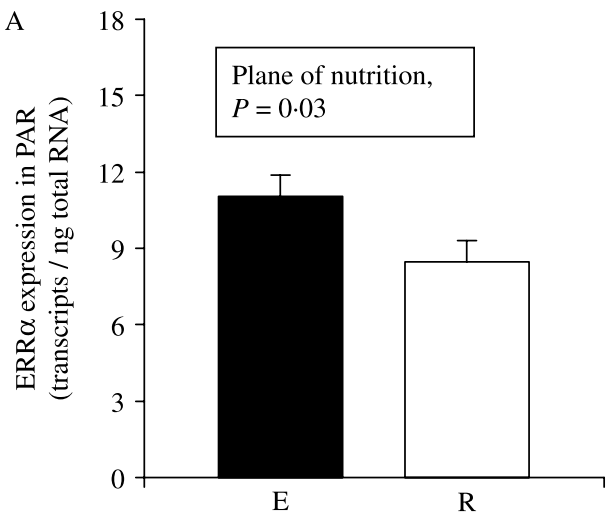

Plane of nutrition

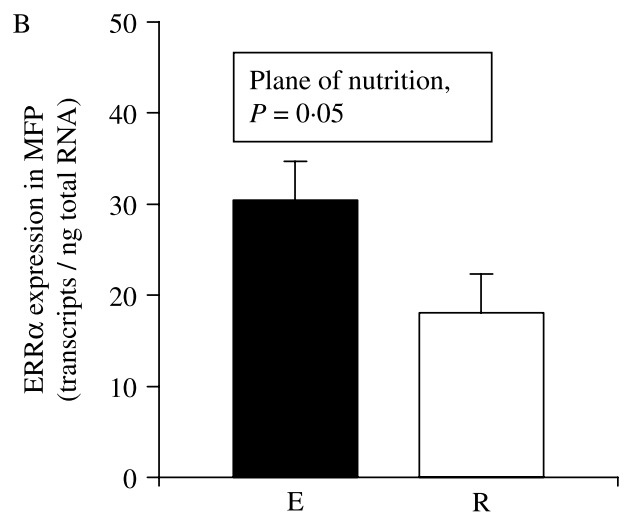

Plane of nutrition

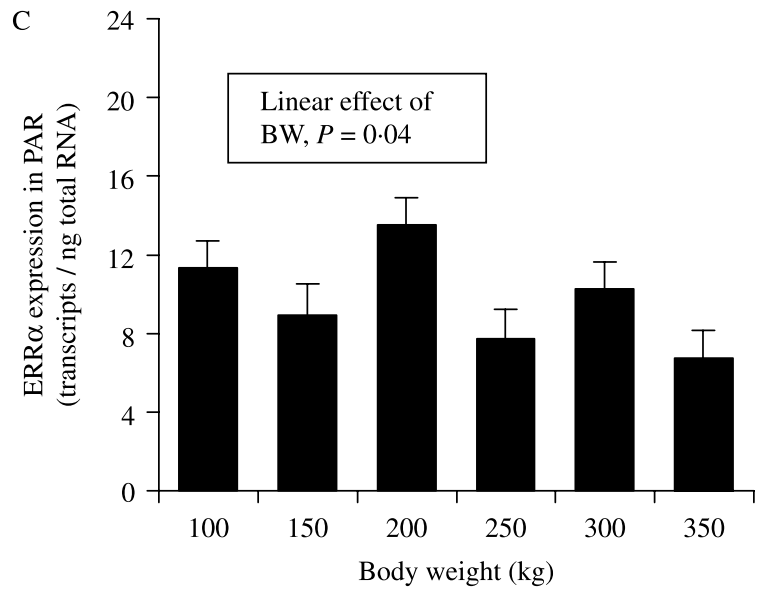

Figure 4 Effect of nutrition and body weight (BW) on expression of the gene encoding estrogen-related receptor $\alpha-1$ (ERR $\alpha$ ) within the mammary parenchyma (PAR) and mammary fat pad (MFP). Dairy heifers were offered a restricted $(R)$ or an elevated (E) plane of nutrition starting at day 10 of age and harvested at fixed BW (100-350 kg). Total RNA was isolated from PAR and MFP and assayed by quantitative RT-PCR for ERR $\alpha$ transcript copy number. In all cases, transcript abundance was normalized to the amount of total RNA used in the reverse transcription reaction. (A) Main effect of plane of nutrition on ERR $\alpha$ transcript abundance in PAR (E (solid bar), $n=27$ versus $\mathrm{R}$ (open bar), $n=28$ ). Bars represent means \pm s.E.M. (B) Main effect of plane of nutrition on ERR $\alpha$ transcript abundance in MFP (E (solid bar), $n=28$ versus R (open bar), $n=26$ ). Bars represent means \pm S.E.M. (C) Main effect of BW on transcript abundance within $\operatorname{PAR}(n=10,8,10,8,10$, and 9 for $100,150,200,250,300$, and $350 \mathrm{~kg}$ respectively). Bars represent means \pm s.E.M. Variation in BW was partitioned into linear, quadratic, and cubic contrasts, and any significant contrast was reported. An effect of BW on ERR $\alpha$ expression in MFP was not detected (data not shown).

proliferation in these same heifers (Meyer et al. 2006c). In contrast, in the MFP, there was a marked decline in IGF-I expression only between 100 and $150 \mathrm{~kg}$, perhaps reflecting the absence of E-dependent regulation of $\mathrm{ER} \alpha$ in this compartment. The effects of development on PR transcript abundance were more variable but appeared similar to IGF-I mRNA abundance (i.e., reduction with BW in PAR but not in MFP). Our study also shows that PR mRNA is expressed at high levels in the PAR at $100 \mathrm{~kg} \mathrm{BW}$, long before progesterone is secreted. The PR is required for ductal branching in the mouse (Brisken et al. 1998). In the bovine, however, ductal branching is initiated long before puberty and therefore before progesterone secretion (Capuco et al. 2002).
In both mice (Shyamala \& Ferenczy 1984) and heifers (Capuco et al. 2002, Schams et al. 2003), PR is localized primarily to mammary epithelial cells. Similarly, abundance of PR mRNA was low in MFP (which is devoid of epithelial cells) and few cells in this mammary compartment stained positive for the PR protein.

In cattle, elevated prepubertal nutrient intake reduces mammary PAR at puberty (Sejrsen et al. 1982, 2000, Capuco et al. 1995). Nutrition, however, has no effect on epithelial cell proliferation or the rate of DNA accumulation in PAR (Meyer et al. 2006c). Rather, we demonstrated that elevated nutrient intake shortens the length of time between birth and puberty, resulting in reduced PAR mass and DNA at puberty, 
A

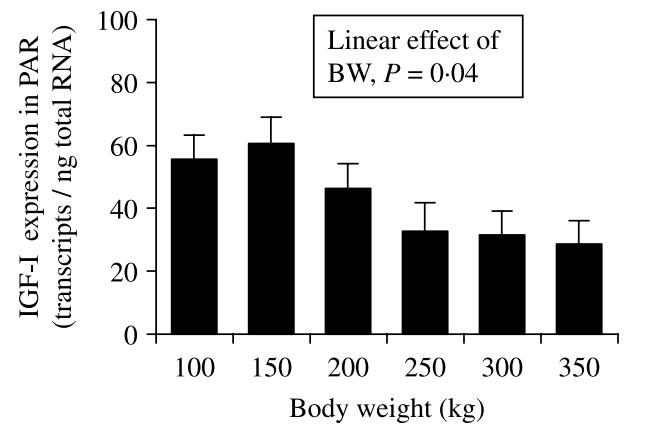

$\mathrm{C}$

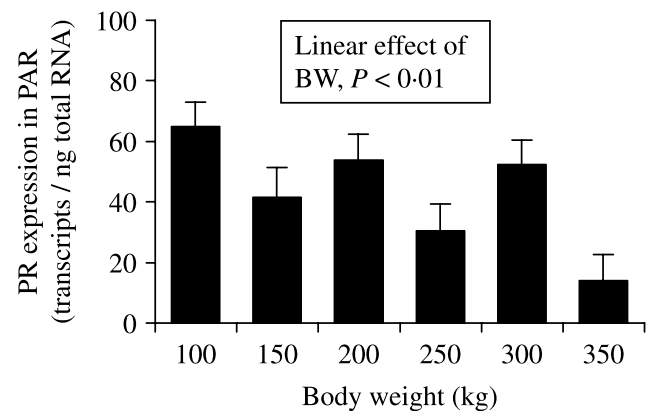

B

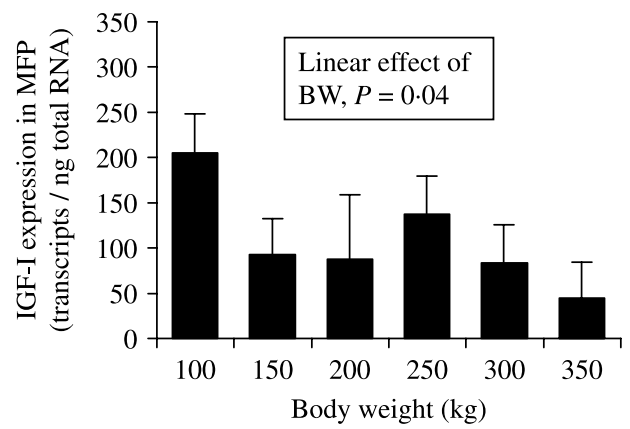

Figure 5 Effect of body weight (BW) on expression of estrogen-responsive genes IGF-I and progesterone receptor $(P R)$ within the mammary parenchyma (PAR) and mammary fat pad (MFP). Dairy heifers were offered a restricted or an elevated plane of nutrition starting at day 10 of age and harvested at fixed BW (100-350 kg). Total RNA was isolated from PAR and MFP and assayed by quantitative RT-PCR for IGF-I transcript copy number. In all cases, transcript abundance was normalized by the amount of total RNA used in the reverse transcription reaction and variation in BW was partitioned into linear, quadratic, and cubic contrasts, and any significant contrast was reported. Plane of nutrition had no effect on transcript abundance of either gene so only main effect of BW is presented. (A) Main effect of BW on IGF-I mRNA abundance in the PAR $(n=9,8,9$, 8,10 , and 10 for $100,150,200,250,300$, and $350 \mathrm{~kg}$ respectively). Bars represent means \pm S.E.M. (B) Main effect of BW on IGF-I mRNA abundance in the MFP $(n=9,10,8,9,9$, and 10 for 100, 150, 200, 250, 300, and $350 \mathrm{~kg}$ respectively). Bars represent means \pm s.E.M. (C) Main effect of BW on PR mRNA abundance in the PAR $(n=10,7,9,9,10$, and 9 for 100, 150, 200, 250, 300, and $350 \mathrm{~kg}$ respectively). Bars represent means \pm s.E.M.

when mammary development is commonly assessed (Meyer et al. 2006c). Consistent with this conclusion, we demonstrated in the current experiment that elevated plane of nutrition had few effects on transcript abundance in the mammary gland. This was the case even for IGF-I, a gene we previously demonstrated to respond dynamically to nutrition in the liver of growing cattle (Smith et al. 2002). This lack of effect is consistent with the data of Weber et al. (2000) who observed similar IGF-I mRNA abundance in the parenchyma of prepubertal heifers growing 0.55 or $1.1 \mathrm{~kg} /$ day. We did see a positive effect of nutrition on ER $\alpha$ expression in the PAR, but this is the opposite of what would be expected if ER were mediating a negative effect of nutrition on PAR growth.

In a previous experiment, we demonstrated that mammary epithelial cell proliferation in the prepubertal bovine decreases from a peak at $100 \mathrm{~kg}$ BW through puberty and beyond (Meyer et al. 2006c). Likewise, in the current study, we observed a concomitant developmental decrease in ER $\alpha$ and IGF-I transcript abundance within both the MFP and PAR. Given the requirement for ovarian secretions in prepubertal mammary development, data presented herein suggest that $\mathrm{ER} \alpha$ and estrogen-responsive IGF-I, in concert, might play a role in developmental regulation of mammary epithelial cell proliferation in the bovine. Strong expression of ER $\alpha$ and IGF-I genes in MFP provides additional evidence that this compartment possesses the ability to influence development of the adjacent PAR via estrogen-responsive paracrine acting hormones, as has been demonstrated in the mouse.

\section{Acknowledgements}

The authors wish to thank Laura Lintault, Denny Shaw, Bruce Berggren-Thomas, Jenny Kelsey-Mills, and Erin Peterson for their help with animal care and tissue collection, and Larry Wood for assessing RNA quality and quantity. Additionally, we 
would like to acknowledge the staff at the Cornell Teaching and Research Center for their assistance with animal care. This research was funded in part by the Cornell University Agriculture Research Station and USDA-ARS (CRIS \#1265-3100-086-00D). Mention of trade names or commercial products is solely for the purpose of providing specific information and does not imply recommendation or endorsement by the US Department of Agriculture. The authors declare that there is no conflict of interest that would prejudice the impartiality of this scientific work.

\section{References}

Brisken C, Park S, Vass T, Lydon JP, O'Malley BW \& Weinberg RA 1998 A paracrine role for the epithelial progesterone receptor in mammary gland development. PNAS 95 5076-5081.

Capuco AV, Smith JJ, Waldo DR \& Rexroad CE Jr 1995 Influence of prepubertal dietary regime on mammary growth of Holstein heifers. Journal of Dairy Science 78 2709-2725.

Capuco AV, Ellis S, Wood DL, Akers RM \& Garrett W 2002 Postnatal mammary ductal growth: three-dimensional imaging of cell proliferation, effects of estrogen treatment, and expression of steroid receptors in prepubertal calves. Tissue and Cell 34 143-154.

Cheng G, Weihua Z, Warner M \& Gustafsson JA 2004 Estrogen receptors ER alpha and ER beta in proliferation in the rodent mammary gland. PNAS 101 3739-3746.

Chomczynski P \& Sacchi N 1987 Single-step method of RNA isolation by acid guanidinium thiocyanate-phenol-chloroform extraction. Analytical Biochemistry 162 156-159.

Connor EE, Wood DL, Sonstegard TS, da Mota AF, Bennett GL, Williams JL \& Capuco AV 2005 Chromosome mapping and quantitative analysis of estrogen-related receptor alpha-1 (ERR $\alpha)$, estrogen receptors alpha $(E R \alpha)$ and beta $(\mathrm{ER} \beta)$ and progesterone receptor (PR) in the bovine mammary gland. Journal of Endocrinology 185 593-603.

Couse JF \& Korach KS 1999 Estrogen receptor null mice: what have we learned and where will they lead us? Endocrine Reviews 20 358-417.

Cunha GR, Young P, Hom YK, Cooke PS, Taylor JA \& Lubahn DB 1997 Elucidation of a role for stromal steroid hormone receptors in mammary gland growth and development using tissue recombinants. Journal of Mammary Gland Biology and Neoplasia 2 393-402.

Ellis S \& Capuco AV 2002 Cell proliferation in bovine mammary epithelium: identification of the primary proliferative cell population. Tissue and Cell 34 21-28.

Evans AC, Adams GP \& Rawlings NC 1994 Follicular and hormonal development in prepubertal heifers from 2 to 36 weeks of age. Journal of Reproduction and Fertility 102 463-470.

Giguere V 2002 To ERR in the estrogen pathway. Trends in Endocrinology and Metabolism 13 220-225.

Imagawa W, Tomooka Y, Hamamoto S \& Nandi S 1986 Regulation of mammary epithelial cell proliferation: an in vitro mouse mammary epithelial cell model system. In Breast Cancer: Orgions, Detection, and Treatment, pp 31-41. Eds MA Rich, JC Hanger \& J Taylor-Papadimitriou. Boston, MA: Martinus Nijhoff.

Kraus RJ, Ariazi EA, Farrell ML \& Mertz JE 2002 Estrogen-related receptor alpha 1 actively antagonizes estrogen receptor-regulated transcription in MCF-7 mammary cells. Journal of Biological Chemistry 277 24826-24834.

Li RW, Meyer MJ, Van Tassell CP, Sonstegard TS, Connor EE, Van Amburgh ME, Boisclair YR \& Capuco AV 2006 Identification of estrogen-responsive genes in the parenchyma and fat pad of the bovine mammary gland by microarray analysis. Physiological Genomics 27 42-53.

Mallepell S, Krust A, Chambon P \& Brisken C 2006 Paracrine signalling through the epithelial estrogen receptor $\alpha$ is required for proliferation and morphogenesis in the mammary gland. PNAS 103 2196-2201.
Meyer MJ, Capuco AV, Boisclair YR \& Van Amburgh ME 2006a Estrogendependent responses of the mammary fat pad in prepubertal dairy heifers. Journal of Endocrinology 190 819-827.

Meyer MJ, Capuco AV, Ross DA, Lintault LM \& Van Amburgh ME $2006 b$ Developmental and nutritional regulation of the prepubertal bovine mammary gland: I. Parenchyma and fat pad mass and composition. Journal of Dairy Science 11 4289-4297.

Meyer MJ, Capuco AV, Ross DA, Lintault LM \& Van Amburgh ME $2006 c$ Developmental and nutritional regulation of the prepubertal bovine mammary gland: II, Allometric growth, epithelial cell proliferation, and the influence of age at slaughter on parenchyma development. Journal of Dairy Science 11 4298-4304.

Mueller SO, Clark JA, Myers PH \& Korach KS 2002 Mammary gland development in adult mice requires epithelial and stromal estrogen receptor alpha. Endocrinology 143 2357-2365.

Purup S, Sejrsen K, Foldager J \& Akers RM 1993 Effect of exogenous bovine growth hormone and ovariectomy on prepubertal mammary growth, serum hormones and acute in vitro proliferative response of mammary explants from Holstein heifers. Journal of Endocrinology 139 19-26.

Ruan W \& Kleinberg DL 1999 Insulin-like growth factor I is essential for terminal end bud formation and ductal morphogenesis during mammary development. Endocrinology 140 5075-5081.

Schams D, Kohlenberg S, Amselgruber W, Berisha B, Pfaffl MW \& Sinowatz F 2003 Expression and localisation of oestrogen and progesterone receptors in the bovine mammary gland during development, function and involution. Journal of Endocrinology 177 305-317.

Sejrsen K, Huber JT, Tucker HA \& Akers RM 1982 Influence of nutrition on mammary development in pre- and postpubertal heifers. Journal of Dairy Science 65 793-800.

Sejrsen K, Purup S, Vestergaard M \& Foldager J 2000 High body weight gain and reduced bovine mammary growth: physiological basis and implications for milk yield potential. Domestic Animal Endocrinology 19 93-104.

Shamay A, Cohen N, Niwa M \& Gertler A 1988 Effect of insulin-like growth factor I on deoxyribonucleic acid synthesis and galactopoiesis in bovine undifferentiated and lactating mammary tissue in vitro. Endocrinology 123 804-809.

Shyamala G \& Ferenczy A 1984 Mammary fat pad may be a potential site for initiation of estrogen action in normal mouse mammary glands. Endocrinology 115 1078-1081.

Silberstein GB 2001 Postnatal mammary gland morphogenesis. Microscopy Research and Technique 52 155-162.

Smith JM, Van Amburgh ME, Diaz MC, Lucy MC \& Bauman DE 2002 Effect of nutrient intake on the development of the somatotropic axis and its responsiveness to GH in Holstein bull calves. Journal of Animal Science $\mathbf{8 0}$ $1528-1537$.

Wallace C 1953 Observations on mammary development in calves and lambs. Journal of Agricultural Science 43 413-421.

Weber MS, Purup S, Vestergaard M, Akers RM \& Sejrsen K 2000 Regulation of local synthesis of insulin-like growth factor-I and binding proteins in mammary tissue. Journal of Dairy Science 83 30-37.

Woodward TL, Beal WE \& Akers RM 1993 Cell interactions in initiation of mammary epithelial proliferation by oestradiol and progesterone in prepubertal heifers. Journal of Endocrinology 136 149-157.

Zhang Z \& Teng CT 2001 Estrogen receptor alpha and estrogen receptorrelated receptor alpha1 compete for binding and coactivator. Molecular and Cellular Endocrinology 172 223-233.

Received in final form 16 June 2007

Accepted 23 July 2007

Made available online as an Accepted Preprint 23 July 2007 